Identification of stable resistance to Phytophthora infestans in potato genotypes evaluated in field experiments in Peru

Wulff, Ednar Gadelha; Pérez, W.; Nelson, R.J.; Bonierbale, M.; Landeo, J.A.; Forbes, G.A.

Published in:

Experimental Agriculture

DOI:

$10.1017 / \mathrm{S} 0014479707004991$

Publication date:

2007

Document version

Publisher's PDF, also known as Version of record

Citation for published version (APA):

Wulff, E. G., Pérez, W., Nelson, R. J., Bonierbale, M., Landeo, J. A., \& Forbes, G. A. (2007). Identification of stable resistance to Phytophthora infestans in potato genotypes evaluated in field experiments in Peru.

Experimental Agriculture, 43, 353-363. https://doi.org/10.1017/S0014479707004991 


\title{
IDENTIFICATION OF STABLE RESISTANGE TO PHYTOPHTHORA INFESTANS IN POTATO GENOTYPES EVALUATED IN FIELD EXPERIMENTS IN PERU
}

\author{
By E. G. WULFF†, W. PÉREZ, R. J. NELSON $\ddagger$ M. BONIERBALE, \\ J. A. LANDEO and G. A. FORBES $\S$ \\ International Potato Center, P. O. Box 1558, Lima 12, Peru
}

(Accepted 12 December 2006)

\begin{abstract}
SUMMARY
In this study, genotype by environment $(\mathrm{G} \times \mathrm{E})$ interactions and phenotypic stability of resistance to Phytophthora infestans, the cause of late blight, were analysed in Peru for 13 potato genotypes, using additive main effects and multiplicative interaction (AMMI) analysis and Huehn's non-parametric test. The potato genotypes were tested in seven experiments over two years in the vicinity of Comas, Peru, an area used by the International Potato Center to screen for resistance to late blight. Results of the two analyses generally correlated and indicated that quantitative resistance to $P$. infestans was stable under field conditions for all the genotypes tested. The first two principal components (PCAl and PCA2) of the AMMI analysis explained $54 \%$ of the $\mathrm{G} \times \mathrm{E}$ interaction sum of squares. A biplot of the two principal components demonstrated a strong year effect in the $\mathrm{G} \times \mathrm{E}$ interaction. By plotting yearly means of the relative area under the disease progress curve (rAUDPC), genotypes could be assigned to one of three resistance categories, resistant, moderately resistant or susceptible, but the need for a more readily applicable and truly quantitative scale for resistance was noted. Based on these studies, standards can be selected for use in screening in the area where they were tested. After further testing in other locations, a standard set drawn from these genotypes could be identified and a quantitative scale developed for evaluation of resistance under short day conditions.
\end{abstract}

\section{INTRODUCTION}

Late blight, caused by the oomycete Phytophthora infestans is the most destructive disease of potato, causing serious yield and economic losses worldwide. Many commercial varieties are susceptible to late blight and must be sprayed regularly with fungicides. Dependence on fungicides has been exacerbated in many areas due to the appearance of new strains of $P$. infestans that are more aggressive than the US-1 clonal lineage that was predominant in most parts of the world prior to 1980 (Day and Shattock, 1997; Flier and Turkensteen, 1999; Miller and Johnson, 2000).

Two phenotypic expressions of host plant resistance to $P$. infestans have been described. One is associated with major genes or R-genes, which confer near immunity against certain races of the pathogen (Vanderplank, 1968). This resistance is referred to as qualitative or race-specific. Solanum demissum (Malcolmson and Black, 1966; Müller and Black, 1952) and S. stoloniferum (Schick et al., 1958) were used as sources of

$\S$ Corresponding author: g.forbes@cgiar.org

$\dagger$ Present address: The Royal Veterinary and Agricultural University, KD 1870, Frederiksberg, Denmark

$\ddagger$ Present address: 321 Plant Science, Cornell University, Ithaca, NY, USA 
qualitative resistance. While it is relatively easy to work with qualitative resistance in a breeding programme, such resistance has been unstable because compatible races of the pathogen are rapidly selected under field conditions. The other type of resistance, called quantitative or race non-specific, is based on the presence of multiple genes of relatively small effect that, in theory, render the host partially resistant to all races of the pathogen (Vanderplank, 1968). Quantitative resistance has been reported in $S$. tuberosum (Turkensteen, 1993; Wastie, 1991) and several wild Solanum species (Colon et al., 1995a). Some American and European varieties (Colon et al., 1995b; James and Fry, 1983; Turkensteen, 1993) as well as clones derived from population B of the International Potato Center (CIP) breeding programme (Landeo et al., 2000) were also reported to possess significant levels of quantitative resistance. This population was developed to be free of $\mathrm{R}$ genes that confer qualitative resistance in an effort to facilitate selection of quantitative resistance. Quantitative resistance is considered more durable and for that reason many potato breeding programmes, including that of CIP, focus on this type of resistance. However, the expression of quantitative resistance can be affected by environmental conditions (Umaerus and Umaerus, 1994), which brings into question its stability across different testing or production conditions.

One way to study phenotypic stability in crop performance trials is through the analysis of genotype by environment $(\mathrm{G} \times \mathrm{E})$ interactions. $\mathrm{G} \times \mathrm{E}$ effects occur when two or more genotypes differ significantly in their response to changing environments. Generally, a $\mathrm{G} \times \mathrm{E}$ interaction can be studied temporally (two or more seasons testing at a location) or spatially (several locations) or a combination of these (Cotes et al., 2002). Various statistical models have been used to evaluate the $\mathrm{G} \times \mathrm{E}$ interaction. The additive main effects and multiplicative interaction (AMMI) analysis is especially recommended when adaptive responses are to be demonstrated (Annicchiarico, 1997). The model uses ANOVA to separate the additive variance from the multiplicative $(\mathrm{G} \times \mathrm{E})$ variance, and then principal component analysis (PCA) to describe the $\mathrm{G} \times \mathrm{E}$ effect (Gauch and Zobel, 1988). Another way to measure $\mathrm{G} \times \mathrm{E}$ interaction is by analysing phenotypic stability with Huehn's non-parametric test of the variance or standard deviations of the ranks of genotypes across the environments (Huehn, 1990a).

Standard potato varieties with known levels of resistance to $P$. infestans were used throughout the twentieth century to aid in the classification of resistance of experimental genotypes (see Hansen et al., 2005 for discussion). Standard varieties have also been used to develop scales of resistance, many of which have values of 1 to 9, either descending and ascending relative to resistance (Darsow, 1989). These scales represent attempts to quantify resistance in a manner that is relatively independent of environment. Recently, Jenkins and Jones (2003) classified cultivars for resistance to $P$. infestans in the United States and to do so they developed a four-level scale based on the area under the disease progress curve (AUDPG). Hansen et al. (2005) proposed an improved scale based on regression analysis whereby researchers can assign scale values using just one standard variety. The varieties used by both groups mentioned above are adapted to long day lengths and to date there are no standard varieties which have been evaluated for short day lengths. 
Identification of appropriate standard cultivars for classifying breeding lines should meet at least two conditions. The resistance of the materials should be stable across environments and the standards should represent a wide range of susceptibilities. The objectives of the present work were to: i) determine the phenotypic stability of 13 potato genotypes adapted to short day lengths, and ii) classify the most stable genotypes with a range of susceptibilities to be part of a set of quantitative resistance standards that would facilitate the interpretation of future field evaluations of resistance to $P$. infestans in this highland tropical environment. Research needs for a quantitative scale for resistance as well as for the use of these standards in other highland tropical areas are discussed.

\section{MATERIALS AND METHODS}

\section{Plant material}

Eight potato cultivars [Ccompis (Peru); Chata Blanca (Peru); Cruza 148 (Mexico); Huayro (Peru); Ingabire (Burundi); Monserrate (Colombia); Pimpernel (Netherlands); Yungay (Peru)] and five experimental genotypes from CIP's breeding programme (386209.10; 387164.4; 387315.27; 387334.5; 387410.7) with different levels of quantitative resistance were used in the experiments. The CIP genotypes were derived from the breeding population B where large-effect R-genes had been systematically eliminated (Landeo et al., 1995). Hereafter, all of these materials are referred to as potato genotypes.

\section{Inoculum}

Plants were exposed to the natural population of $P$. infestans. The clonal lineage EC1 of $P$. infestans, belonging to 'new' pathogen population (sensu Spielman et al., 1991), is predominant in the Peruvian Andes (Perez et al., 2001) and is assumed to have been the pathogen infecting plants in all the experiments.

\section{Field experiments}

For logistical reasons, each of the seven experiments was paired to a resistance screening trial of the CIP late blight breeding programme. All experiments were carried out near the community of Mariscal Castilla (2800 m asl, $11^{\circ} 42^{\prime} 54^{\prime \prime} \mathrm{S}$ latitude) near Comas, Peru. This is a location of consistently high disease pressure and for that reason is used by CIP for yearly screening of populations of potato genotypes segregating for resistance to $P$. infestans. Five trials were conducted between 1999 and 2000 and two trials between 2000 and 2001 (Table 1). Tubers were planted into commercial substrate (Jiffystrips ${ }^{\circledR}$, Product 300522; Jiffy Products (N.B.) Ltd. Shippagan, Canada) and grown in the greenhouse for 45 days at the CIP Huancayo station $(3200 \mathrm{~m}$ asl) and then transplanted in the field. Trials were transplanted in the first two weeks of December each year (Table 1). Planting density was $0.9 \mathrm{~m}$ between rows and $0.3 \mathrm{~m}$ between plants, except in one experiment in 1999-2000 when intra-plant distance was $0.4 \mathrm{~m}$. Fertilizer application was $90 \mathrm{~kg} \mathrm{~N} \mathrm{ha}^{-1}, 70 \mathrm{~kg}$ $\mathrm{P} \mathrm{ha}^{-1}$ and $120 \mathrm{~kg} \mathrm{~K} \mathrm{ha}^{-1}$ at transplanting and $90 \mathrm{~kg} \mathrm{~N} \mathrm{ha}^{-1}$ at the stem elongation 
Table 1. Characteristics of experiments implemented in two seasons (1999-2000 and 2000-2001) in the vicinity of Comas, Peru to evaluate stability of resistance to Phytophthora infestans in potato genotypes.

\begin{tabular}{|c|c|c|c|c|c|c|c|}
\hline \multirow[b]{3}{*}{ Experiment information } & \multicolumn{7}{|c|}{ Year and experiment code } \\
\hline & \multicolumn{5}{|c|}{$1999-2000^{\dagger}$} & \multicolumn{2}{|c|}{$2000-2001^{\dagger}$} \\
\hline & $1 \mathrm{~A}$ & $2 \mathrm{~A}$ & $3 \mathrm{~A}$ & $4 \mathrm{~A}$ & $5 \mathrm{~A}$ & $1 \mathrm{~B}$ & $2 \mathrm{~B}$ \\
\hline Experimental design & $\mathrm{RCB}^{\ddagger}$ & RCB & $\begin{array}{l}\text { Lattice } \\
12 \times 12\end{array}$ & $\begin{array}{l}\text { Lattice } \\
12 \times 12\end{array}$ & $\begin{array}{l}\text { Lattice } \\
12 \times 12\end{array}$ & $\begin{array}{l}\text { Rect. Lattice } \\
12 \times 13\end{array}$ & $\begin{array}{l}\text { Rect. Lattice } \\
12 \times 13\end{array}$ \\
\hline Replications & 2 & 4 & 4 & 4 & 4 & 6 & 4 \\
\hline Genotypes tested $^{\S}$ & 13 & 12 & 13 & 13 & 13 & 8 & 11 \\
\hline Planting date & $15 / 12 / 99$ & $7 / 12 / 99$ & $14 / 12 / 99$ & $14 / 12 / 99$ & $14 / 12 / 99$ & $15 / 12 / 00$ & $15 / 12 / 00$ \\
\hline Harvest date & $28 / 03 / 00$ & $7 / 04 / 00$ & $17 / 03 / 00$ & $17 / 03 / 00$ & $17 / 03 / 00$ & $16 / 03 / 01$ & $16 / 03 / 01$ \\
\hline Plot size & $3 \mathrm{~m}^{2}$ & $3 \mathrm{~m}^{2}$ & $69.4 \mathrm{~m}^{2}$ & $69.4 \mathrm{~m}^{2}$ & $69.4 \mathrm{~m}^{2}$ & $97.9 \mathrm{~m}^{2}$ & $97.9 \mathrm{~m}^{2}$ \\
\hline
\end{tabular}

${ }^{\dagger}$ Potato is planted in the last quarter of the year and harvested in the first quarter.

${ }^{\ddagger}$ Randomized complete block design.

$\S$ Values for missing genotypes were estimated based on average ranking; see Materials and Methods for details.

IThis refers to date of transplanting of pre-planted tubers.

stage. Insecticides (Metaldehyde, Lamdacyhalothrin and Deltametrine) were applied to control slugs, potato tuber moths and potato flea beetles when necessary. Plants were protected against $P$. infestans with a contact fungicide (Mancozeb $45 \%$ ) for the first 25 days after transplanting, after which they were exposed to natural infection with no further fungicide applications. The experiments were carried out in a lattice square or randomized complete block design with 2-6 replications (Table 1).

\section{Evaluation of late blight resistance in the field}

The percentage of total leaf area with symptoms of late blight was recorded for each plot at 7-day intervals, beginning 32 days after transplanting, for a total of 7-9 readings per experiment. The AUDPG was calculated for each plot from the estimates of foliar infection using the midpoint method (Campbell and Madden, 1990). To help standardize AUDPG values across years, this metric was converted to the relative AUDPC (rAUDPC) as described previously (Fry, 1978).

\section{Statistical analysis}

Phenotypic stability was evaluated with two statistical procedures: the AMMI analysis (Gauch and Zobel, 1988) and the non-parametric test of Huehn (1990b). AMMI analysis considers additive effects for main effects and multiplicative effects for the genotype-environment interaction term (Ibañez et al., 2001). The Huehn test is based on the rAUDPC rankings of the genotypes within each trial. In this test, a genotype is considered stable if it is ranked similarly in different experiments. Smaller values of Huehn's variables S1 and S2 indicate stability. In some trials some values were missing for certain genotypes. Missing values were replaced by the average rank of the cultivar over the experiments. For trial 2A, estimated missing data were used for Huayro. For trial 1B, estimated missing data were used for Ccompis, Cruza 148, 
Huayro, Monserrate and genotype CIP 387334.5. For trial 2B, estimated missing data were used for Chata Blanca and Ingabire (Table 1). All statistical analyses were done with the program $R$ ( $R$ Foundation for Statistical Computing, Vienna).

\section{RESULTS}

There was a wide range in resistance reactions among the 13 genotypes tested, with the most resistant having rAUDPC values of less than 0.2 and the most susceptible with values of between 0.6 and 0.8 (Figure 1). There was also a good distribution of genotypes between high and low values, with several materials having intermediate values.

The plot of yearly average rAUDPC values indicated that the cultivars had similar relative resistance levels in the two years. Most clones had slightly higher rAUDPC values the first year. Values for Cruza 148 and Yungay were slightly higher in the second year, but the value for Cruza 148 may have been biased by small sample size as it was present in only one of the two experiments.

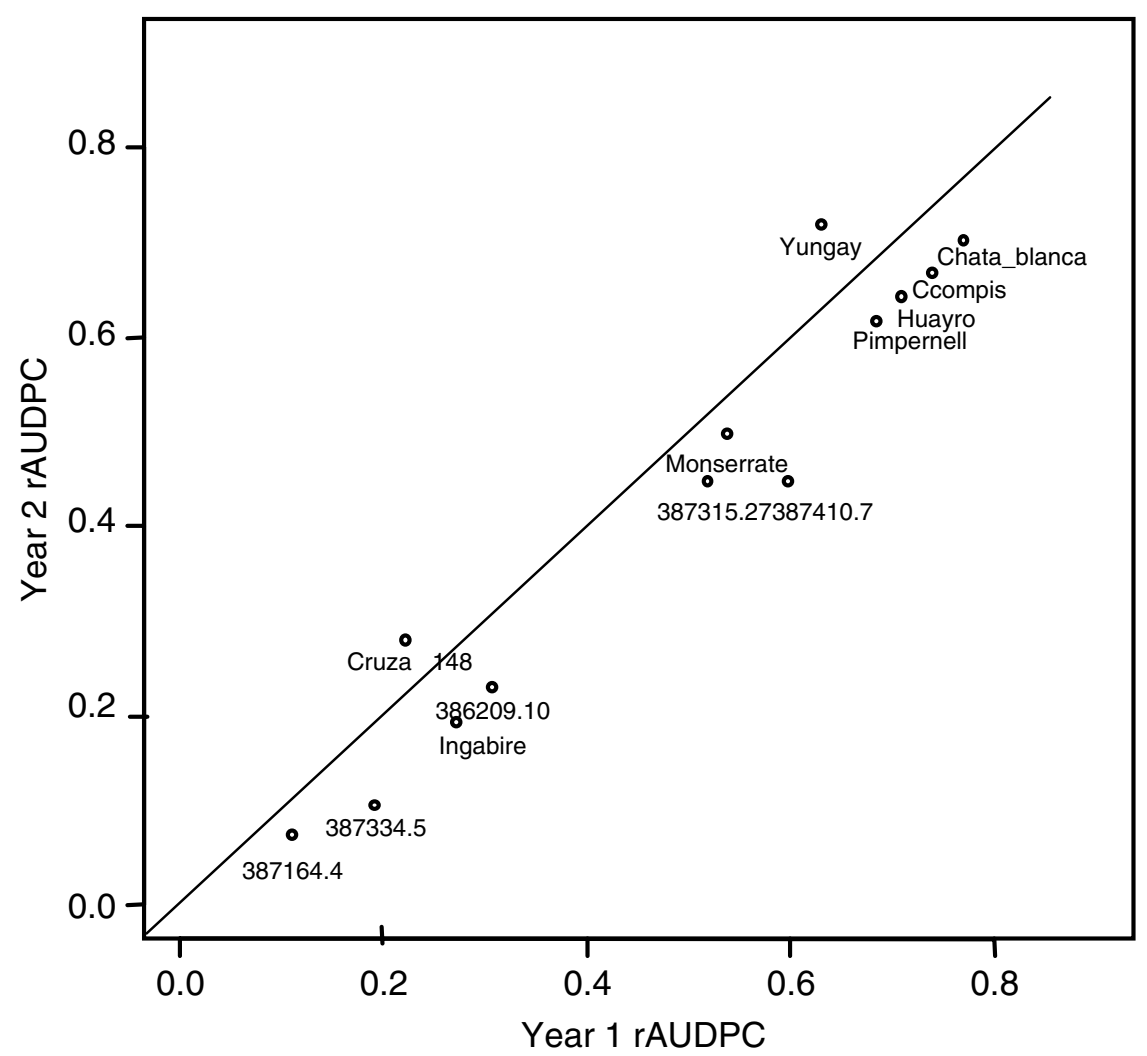

Figure 1. Comparison of yearly average relative area under the disease progress curve (rAUDPC) values of 13 potato genotypes evaluated for resistance to Phytophthora infestans in seven field experiments implemented near Comas, Peru, in 1999-2000 and 2000-2001. The diagonal line represents identical values for the two years. 
Table 2. Additive main effects and multiplicative interactions analysis of variance (AMMI) for resistance to Phytophthora infestans in a set of potato genotypes tested in seven trials.

\begin{tabular}{lrccrrr}
\hline & d.f. & Sum of squares & Mean square & $F^{\dagger}$ & $P$ & Explained $(\%)^{\ddagger}$ \\
\hline Environment (ENV) & 6 & 1.57 & 0.2619 & 31.40 & $<0.0001$ & \\
Genotype (GEN) & 12 & 16.10 & 1.3419 & 160.89 & $<0.0001$ & \\
ENV:GEN & 64 & 0.90 & 0.0141 & 1.69 & 0.0025 & \\
PC 1 & 17 & 0.28 & 0.0165 & 1.99 & 0.0124 & 31.2 \\
PC 2 & 15 & 0.20 & 0.0135 & 1.63 & 0.0663 & 22.5 \\
Error & 239 & 1.99 & 0.0083 & & & \\
\hline
\end{tabular}

${ }^{\dagger} F$ tests were done using the error mean square as a denominator.

${ }^{\ddagger}$ Percentage of $\mathrm{G} \times \mathrm{E}$ interaction explained by components.

The AMMI analysis indicated that the genotype, environment and $\mathrm{G} \times \mathrm{E}$ effects were highly significant (Table 2), although the variance associated with genotype was much greater than that associated with the other two effects. In this analysis, PCA 1 and PCA 2 accounted for slightly over $50 \%$ of the variance. Based on the projection of these two principal components, two groups of trials can be detected (Figure 2). The first group included all those from 1999-2000, while the second comprised the two trials in 2000-2001. The second principal component was defined primarily by the separation of years. Varieties Cruza 148 and Yungay were most closely associated with the second year trials in this projection, which is consistent with the projection of yearly average rAUDPG values (Figure 1 ).

Although, none of the cultivars was considered significantly unstable in the Huehn test, where the individual values of $\mathrm{Z} 1$ and $\mathrm{Z} 2$ for all the genotypes were lower than the $\chi^{2}$ value of 8.35 (Table 3), Yungay was the least stable with an S1 value of 5.71.

\section{DISCUSSION}

The selection of superior genotypes with stable resistance and good adaptation to a wide range of environments is the main goal of potato late blight breeding programmes. A standard set of genotypes with a range of known and stable responses to late blight can be a very useful tool in this selection process. It can help to monitor the level of resistance of the tested plant materials as well as to monitor the disease pressure in the different environments. In our study, the 13 genotypes represented a broad span of resistance levels that was generally consistent in seven experiments conducted over two years. These seven trials were all done in the general location where CIP screens potato genotypes for resistance to $P$. infestans. Results obtained from the AMMI analysis, and the Huehn test, indicated that the 13 genotypes were phenotypically stable and were ranked similarly in each experiment.

This test identified materials stable in one location, and the results will be immediately applicable for CIP's screening work in Peru. The results are also generally consistent with other recent field trials for resistance to $P$. infestans in potato that demonstrated general stability of resistance across locations, both within the United 


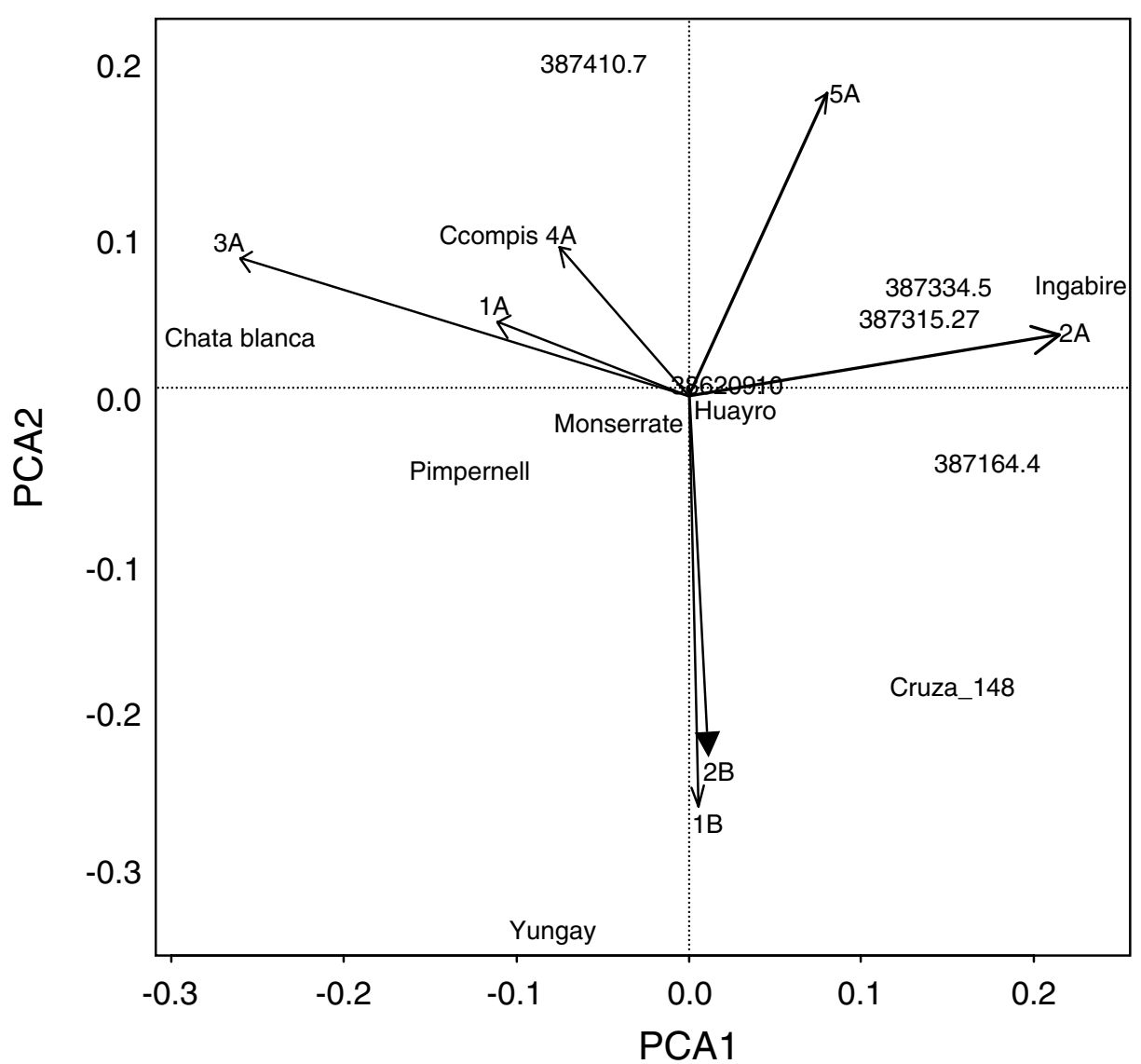

Figure 2. Biplot of first and second principal components (PCA1 and PCA2, respectively) from additive main effects and multiplicative interaction (AMMI) model for seven experiments (and 13 potato genotypes). Experiments are indicated by arrows (see Table 1 for details). Those experiments and genotypes farthest from the centre contributed most to the genotype by environment $(\mathrm{G} \times \mathrm{E})$ interaction. PCAl and PCA2 together explained $53.7 \%$ of the $\mathrm{G} \times \mathrm{E}$ interaction.

States (Haynes et al., 1998) and more recently in an international trial (Forbes et al., 2005).

Although our results for specific genotypes should only be extrapolated to other locations with caution, we feel that it is safe to assume that most of the genotypes tested here would be broadly adapted to the highland tropics and would maintain their relative levels of resistance. Several genotypes have been grown successfully in Latin America or Africa, or tested in Asia. Cruza 148 is grown widely in Burundi, Rwanda and parts of the Democratic Republic of Congo where it has maintained its level of resistance for decades (unpublished data). Monserrate is an established variety in Colombia and in one study conducted in India by Gopal and Singh (2003) it was also found to be moderately resistant. Ccompis and Huayo are native potatoes cultivated in different parts of Peru. Several of the genotypes used in the present study 
Table 3. Mean relative area under the disease progress curve rAUDPG, rankings of the potato genotypes from lowest to highest, mean of absolute rank differences of a clone (S1), approximate test of significance of S1 (Z1), common variance of the ranks (S2) and approximate test of significance of S2 (Z2) from Huhn's test for stability.

\begin{tabular}{lcccccc}
\hline Genotype† & $\begin{array}{c}\text { Mean } \\
\text { rAUDPC }\end{array}$ & Rank & S1 & Z1 & S2 & Z2 ${ }^{\ddagger}$ \\
\hline 387164.4 & 0.10 & 1 & 4.00 & 0.11 & 10.81 & 0.32 \\
387334.5 & 0.17 & 2 & 4.67 & 0.14 & 14.67 & 0.01 \\
Cruza 148 & 0.23 & 3 & 4.48 & 0.03 & 14.62 & 0.01 \\
Ingabire & 0.28 & 4 & 5.05 & 0.62 & 17.33 & 0.35 \\
386209.10 & 0.32 & 5 & 4.67 & 0.14 & 17.24 & 0.33 \\
387315.27 & 0.50 & 6 & 5.24 & 0.97 & 18.24 & 0.57 \\
Monserrate & 0.52 & 7 & 4.95 & 0.47 & 16.95 & 0.28 \\
387410.7 & 0.57 & 8 & 5.43 & 1.41 & 19.81 & 1.08 \\
Yungay & 0.66 & 9 & 5.71 & 2.23 & 22.62 & 2.37 \\
Pimpernell & 0.68 & 10 & 4.10 & 0.05 & 12.48 & 0.07 \\
Huayro & 0.71 & 11 & 4.00 & 0.11 & 11.67 & 0.17 \\
Ccompis & 0.74 & 12 & 4.48 & 0.03 & 13.81 & 0.00 \\
Chata Blanca & 0.78 & 13 & 5.05 & 0.62 & 17.81 & 0.46 \\
\hline
\end{tabular}

${ }^{\dagger}$ Values for some of 13 potato genotypes were estimated in some locations (see Materials and Methods). $\ddagger Z$ statistics are stability parameters. The tests for the significance of the sum of $Z 1$ or $Z 2$ are compared to a $\chi^{2}$ value of 22.36. Individual $Z 1$ or $Z 2$ are compared to a $\chi^{2}$ value of 8.35 .

(Monserrate, Pimpernel, Chata Blanca, Cruza 148 and Yungay) were included in a recent international $\mathrm{G} \times \mathrm{E}$ study, which also confirmed the general stability of their relative resistance levels across locations (Forbes et al., 2005). As in our study, Chata Blanca, Huayro and Yungay were found to be susceptible to highly susceptible to late blight in a study conducted by Gopal and Singh (2003) in a highland sub-tropical location in India.

In our study, all genotypes of the population B were moderately resistant to resistant. This is a population that was developed for late blight resistance and this level of resistance was expected (Landeo et al., 1995). A similar performance was reported when other genotypes of Population B were tested in the highlands of Uganda (Mulema et al., 2004).

One cultivar that has not given consistent results in historical and recent studies is Pimpernel. This old European cultivar has been used as a resistant control in earlier studies in Europe (Colon et al., 1995b), but was found to be susceptible in our study. This genotype was also reported to be highly susceptible in experiments conducted in India (Gopal and Singh, 2003).

Evaluation of all of these materials across a wider geographic area would reinforce assumptions regarding the stability of resistance. CIP is at this time seeking collaboration from partners in Asia and Africa to grow this set of genotypes to confirm the relative resistance levels. Once that is done, a small number of cultivars would be chosen for use in screening areas with short day length. Co-ordination of common use of a standard set of varieties is feasible because of the important role CIP plays in providing germplasm to many national potato programmes. Germplasm is distributed 
with guidelines on its evaluation for agronomic and phyto-sanitary characteristics. Standard varieties and guidelines for their use would be distributed with germplasm and could also be made available via on-going collaborative research projects.

In our study, the first two principal components of the AMMI analysis explained slightly over half of the $\mathrm{G} \times \mathrm{E}$ variation under field conditions and the projection of locations and genotypes along these components suggested a strong year effect in the $\mathrm{G} \times \mathrm{E}$ interaction. Initial attempts to include 'year' as a variable in the analysis were abandoned because of lack of precedent for using the AMMI model for nested designs and because of the small number of trials in the second year.

Since our study did not provide strong evidence for rejection of any of the materials as potential standards for quantitative resistance, we propose that choosing standards from among this group should rely on the level of resistance and additional criteria, which may include agronomic factors that affect multiplication and productivity. The plot of yearly rAUDPG means is illustrative for selection based on relative resistance. Any of several genotypes, including Chata Blanca, Ccompis, Huayo and Yungay, may serve as susceptible controls. However, the somewhat higher value of Yungay in the second year, may make this choice less clear. Genotypes 3873122, Monserrate, 387315.27 and 387410.7 are apparently good candidates for moderately resistant clones. Cruza 148, 395209.10 and Ingabire may be considered resistant, while 387334.5 and 387164.4 are highly resistant.

Identifying stable genotypes with different levels of resistance represents only part of what is needed for the standardization of resistance measurement in tropical locations around the world. Efforts to standardize this process in Europe have also involved the development of several scales, although only recently has there been an attempt to develop a generally applicable and truly quantitative scale with a clear procedure for assigning values (Hansen et al., 2005). No such efforts have been proposed for evaluation of potatoes in the short day lengths of the tropics where the standard cultivars of Europe and the US are poorly adapted. Data reported here could be an important resource for the development of a quantitative resistance scale for short day conditions.

Acknowledgements. We would like to thank Dr. Consuelo Arellano and Mr. Felipe de Mendiburu for help with the statistical analysis. Our thanks are also due to the staff of the Late Blight Laboratory, Department of Genetic Resources and Crop Improvement and Huancayo Experimental Station at CIP for their help during the different stages of this work.

\section{REFERENCES}

Annicchiarico, P. (1997). Additive main effects and multiplicative interaction (AMMI) analysis of genotype-location interaction in variety trials repeated over years. Theoretical and Applied Genetics 94:1072-1077.

Campbell, G. L. and Madden, L. V. (1990). Introduction to Plant Disease Epidemiology. New York: John Wiley and Sons.

Colon, L. T., Jansen, R. C. and Budding, D. J. (1995a). Partial resistance to late blight (Phytophthora infestans) in hybrid progenies of four South American Solanum species crossed with diploid. S. tuberosum. Theoretical and Applied Genetics 90:691-698. 
Colon, L. T., Turkensteen, L. J., Prummel, W., Budding, D. J. and Hoogendoorn, J. (1995b). Durable resistance to late blight (Phytophthora infestans) in old potato cultivars. European Fournal of Plant Pathology 101:387-397.

Cotes, J. M., Nuñez, C. E., Martinez, R. and Estrada, N. (2002). Analyzing genotype by environment interaction in potato using yield-stability index. American Fournal of Potato Research 79:211-218.

Darsow, U. (1989). Ermittlung der relativen Krautfauleresistanz (Phytophthora infestans) (Mont.) de Bary der kartoffel in Feldprufung. Archiv Fur Phytopathologie und Pflanzenschutz 25:137-143.

Day, J. P. and Shattock, R. C. (1997). Aggressiveness and other factors relating to displacement of populations of Phytophthora infestans in England and Wales. European Fournal of Plant Pathology 103:379-391.

Flier, W. G. and Turkensteen, L. J. (1999). Foliar aggressiveness of Phytophthora infestans in three potato growing regions in the Netherlands. European Fournal of Plant Pathology 105:381-388.

Forbes, G. A., Chacón, G., Kirk, H. G., Huarte, M., Damme, M. V., Distel, S., Capezio, S., Mackay, G., Stewart, H., Lowe, R., Duncan, J., Mayton, H., Fry, W. E., Andrivon, D., Ellissèche, D., Pellé, R., Platt, H., MacKenzie, G., Tarn, R., Colon, L. T., Budding, D. J., Lozoya-Saldaña, H. and Hernandez-Vilchis, A. (2005). Stability of resistance to Phytophthora infestans in potato: an international evaluation. Plant Pathology 54:364-372.

Fry, W. E. (1978). Quantifying effects of general resistance and fungicide for management of potato late blight. In $3 r d$ : International Congress of Plant Pathology, 318 Munchen, Germany.

Gauch, H. G. and Zobel, R. W. (1988). Predictive and postdictive success of statistical analyses of yeild trials. Theoretical and Applied Genetics 76:1-10.

Gopal, J. and Singh, B. P. (2003). Screening potatoes for resistance to late blight (Phytophthora infestans) under field conditions. Potato Research 46:47-56.

Hansen, J. G., Koppel, M., Valskyte, A., Turka, I. and Kapsa, J. (2005). Evaluation of foliar resistance in potato to Phytophthora infestans based on an international field trial network. Plant Pathology 54:169-179.

Haynes, K. G., Lambert, D. H., Christ, B. J., Weingartner, D. P., Douches, D. S., Backlund, J. E., Secor, G., Fry, W. and Stevenson, W. (1998). Phenotypic stability of resistance to late blight in potato clones evaluated at eight sites in the United States. American Fournal of Potato Research 75:211-217.

Huehn, M. (1990a). Nonparametric measures of phenotypic stability. Part 1: Theory. Euphytica 47:189-194.

Huehn, M. (1990b). Nonparametric measures of phenotypic stability. Part 2: Applications. Euphytica 47:195-201.

Ibañez, M. A., Di Renzo, M. A., Samame, S. S., Bonamico, N. C. and Poverne, M. M. (2001). Genotypeenvironment interaction of lovegrass forage yield in the semi-arid region of Argentina. Fournal of Agricultural Science Cambridge 137:329-336.

James, R. V. and Fry, W. E. (1983). Potential for Phytophthora infestans populations to adapt to potato cultivars with rate-reducing resistance. Phytopathology 73:984-988.

Jenkins, J. C. and Jones, R. K. (2003). Classifying the relative host reaction in potato cultivars and breeding lines to the US-8 strain of Phytophthora infestans in Minnesota. Plant Disease 87:983-990.

Landeo, J. A., Gastelo, M., Pinedo, H. and Flores, F. (1995). Breeding for horizontal resistance to late blight in potato free of R genes. In Phytophthora infestans 150, 268-274 (Eds L. J. Dowley, E. Bannon, L. R. Cooke, T. Keane and E. O'Sullivan). Dublin: Boole Press.

Landeo, J. A., Gastelo, M., Roncal, E. and Mendoza, A. (2000). Phenotypic stability for horizontal resistance to potato late blight in population B. American fournal of Potato Research 77:406.

Malcolmson, J. F. and Black, W. (1966). New R genes in Solanum demissum Lindl. and their complementary races of Phytophthora infestans (Mont.) de Bary. Euphytica 15:199-203.

Miller, J. S. and Johnson, D. A. (2000). Competitive fitness of Phytophthora infestans isolates under semiarid field conditions. Phytopathology 90:220-227.

Mulema, J.M.K., Olanya, O.M., Adipala, E. and Wagoire, W. (2004). Stability of late blight resistance in population B potato clones. Potato Research 47:11-24.

Müller, K. O. and Black, W. (1952). Potato breeding for resistance to late blight and virus disease during the last hundred years. Zeitschrift fur Pflanzenzuchtung 31:225-236.

Perez, W. G., Gamboa, J. S., Falcon, Y. V., Coca, M., Raymundo, R. M. and Nelson, R. J. (2001). Genetic structure of Peruvian populations of Phytophthora infestans. Phytopathology 91:956-965.

Schick, R., Schick, E. and Haussdorfer, M. (1958). Ein Beitrag zur physiologischen spezialisierun von Phytophthora infestans. Phytopathologische Zeitschrift 31:225-236.

Spielman, L. J., Drenth, A., Davidse, L. C., Sujkowski, L. J., Gu, W., Tooley, P. W. and Fry, W. E. (1991). A second world-wide migration and population displacement of Phytophthora infestans? Plant Pathology 40:422430. 
Turkensteen, L. J. (1993). Durable resistance of potatoes against Phytophthora infestans. In: Durability of Disease Resistance, 115-124 (Eds T. Jacobs and J. E. Parlevliet). Dordrecht, The Netherlands: Kluwer Academic Publishers.

Umaerus, V. and Umaerus, M. (1994). Inheritance of resistance to late blight. In: Potato Genetics, 365-402 (Eds J. E. Bradshaw and G. R. Mackay), Wallingford, UK: CAB International.

Vanderplank, J. E. (1968). Disease Resistance in Plants. New York: Academic Press.

Wastie, R. L. (1991). Breeding for resistance. In: Phytophthora infestans: The Cause of Late Blight of Potato, Vol. 7, 193-224 (Eds D. S. Ingram and P. H. Williams). San Diego, CA, USA: Academic Press. 